\title{
ANALYSIS OF FACTORS THAT AFFECT CHINESE PEOPLE'S DECISION OF CHINA STATE-OWNED COMMERCIAL BANKS
}

\author{
Siska Purnama Manurung and Chen Ke \\ President University, Jl. K.H. Dewantara, Jababeka, Cikarang, Indonesia - 17550
}

\begin{abstract}
The purpose of this study is to examine Chinese people's decision of China state-owned commercial banks, the Chinese people that stay in Greater Jakarta area, Indonesia. The study included four independent variables (service provision, government support, online bank services, bank perceived security) and a dependent variable (Chinese people's decision). Researchers used quantitative studies to study the data, which was collected using questionnaires. A total of 265 questionnaires were valid in this study. Multivariate regression tests were performed using the $T$ test (partial test) and $F$ test (simultaneous test) hypothesis test to analyze the effect of the dependent variable on the dependent variable. Data analysis uses SPSS 2O.O to generate results. The findings of this study that service provision does not have a significant impact on Chinese people's decision, the three variables of government support, online bank services and bank perceived security have a significant impact on Chinese people's decision. At the same time, these three important independent variables provide $41.9 \%$ of the dependent variable.
\end{abstract}

Keywords: Service provision; government support; online bank services; bank perceived security; decision. 


\section{INTRODUCTION}

\subsection{Background}

In the globalization era, China as a main emerging and transition economy has since 2006 opened up its banking market to foreign competition. With rapid economic growth, people income increase and exposure to international consumer culture.In modern China, people's demand for saving and spending is becoming higher. For example, the number of credit cards issued by Chinese banks has increased from 140 million in 2008 to 455 million in 2014(Chan, Tsang, \& Chen, 2017).

With the development of China economy, banking services and financial services demand of people becoming increasingly, bank plays an important role in the development of country's economy. In order to improve the efficiency of banking industry in China, like many developing countries, China's financial system has also gradually deepened with the reform and opening up policy (Yin \& Matthews, 2017).In 1978, China' financial system has undergone a series of evolutions. The following is main four state-owned banks: Bank of China (BOC), China Construction Bank (CCB), Agricultural Bank of China (ABC) and Industrial and Commercial Bank of China (ICBC), which also known as the "Big Four". "Big Four" were established to take over the commercial banking businesses of the People's Bank of China, Bank of China (BOC) focus on the field of foreign trade, Industrial and Commercial Bank of China (ICBC) in the industrial field; China Construction Bank (CCB) specializes in the field of infrastructure finance, Agricultural Bank of China (ABC) concentrate on the agricultural sector. These 'big four' have constituted the core of the banking business in China. They commercialized to enhance their profitability and cancelled restrictions on lending interest rates, and then, they also introduced deposit insurance system (Chan, Tsang, \& Chen, 2017).

In 1997, Chinese government starts a comprehensive banking reform, with the aim of transforming banks into market functioning and profitable institutions. The four state-owned commercial banks (SOCBs) which serve as the lending arms of the state-owned enterprises (SOEs) are the main objective of the reform(Yin \& Matthews, 2017).

In 2014, five private banks, 13 privately controlled financial companies and 162 village and township banks were license(Chan, Tsang, \& Chen, 2017). As competition increases, higher level of transparency in China banking industry also becoming necessary to attract people, like depositors and creditors (Jin, Liu, Liu, \& Yin, 2014).

Bank industry moving into a more competitive financial environment, banks providedifferent kinds of financial products/services to improve banks services, include local banks and stated-own commercial banks. In China market, no bank can provide all financial products that satisfied people's need, and become the best/leading bank for all people.In the financial services market, intense competition is a big challenge to the profitability of all sizes of banking institutions. The competition and saturation in the banking industry requires banks to be people oriented. People also faced diversified bank choices and they always concerned on the value for money, that means people can change banks to satisfy their own demand(Zhang, Dong, \& Zhu, 2012).

Since China joined the WTO in 2001,China government allowed foreign banks to enter China bank market and carry out business activities. In the previous period, there are restrictions for foreign banks; they were not allowed to provide all of financial services or 
products in China. But now, with the liberalization of policy, foreign banks get more development opportunities. It formed China's banks and foreign banks into a competition situation.In recent years, as the scale of e-commerce transactions in China has been continuously increasing and the growth rate has been on an upward trend, the total transaction volume increased year by year from 2013. In 2015, the overall transaction scale of China's e-commerce market was 16.2 trillion yuan, it forming a situation of mobile payment and banks competition. The market sharesof banksdiminish gradually, especially China state-owned commercial banks. Since then, China's banks start to transit to a more comprehensive, more consumer-focused organization, not just have deposits and loans services(Zhang, Dong, \& Zhu, 2012).

\subsection{ProblemI dentification}

In modern society, the Internet has become more and more convenient. With the popularity of E-banking, mobile banking and e-payment, there is a new channel of financial management and payments. In the first half of 2016, online payment users in China increased by 9 percent, and banking online users in China increased by 12 percent(Chan, Tseng \& Chen, 2017).Especially, in 2012, business and personal internet banking transactions replaced more than half of over-the-counter transactions in China. Alipay and AliFinance launched by Alibaba as innovative digital financial services have become popular means for online payments and online loans. People always choose a more convenient financial services way (Xiu, et al., 2016).

With the market growing and consumer demand increasing, China bank industry becoming more and more challenging and competitive by globalization and government regulation.
As the local and foreign banks develop in China, China state-owned commercial banksarerespond to these challenges and adopt consolidation by provide more wide range of financial services and product (Chan, Tseng \& Chen, 2017).

Different banks provide a wide variety of products or services, like small and medium-sized in China. Over 95\% of China's banks are small and mediumsized banks, a great number of small and medium-sized banks have become an important part of our financial system. After more than 30 years of development and growth, small and medium-sized banks have huge financial resources. Therefore, state-owned banks are also facing challenges and hit its status. China state-owned banks have to consider how to build and protect its competitive position in market, in order to get more competition basis, finding what the main factors that affect people choose state-owned commercial banks in China attract attention of researchers, analyzing the problems that existing and state-owned commercial banks can improve service(Zineldin, 2017).

Figure 1.1 showed the China stateowned commercial banks net income and increasing trend from 2012-2016. In the first three years, the net income of state-owned commercial banks had a rising tendency year by year. From 2014-2016, net income showed a slowly toward stable trend. About the increasing trend, it declined year by year, and had a turning point in 2014.The increasing trend rate decreased rapidly from 20142015 and showed a steady trend from 2015-2016. In general, the increasing trend rate became lower than before and had a decreasing trend. 


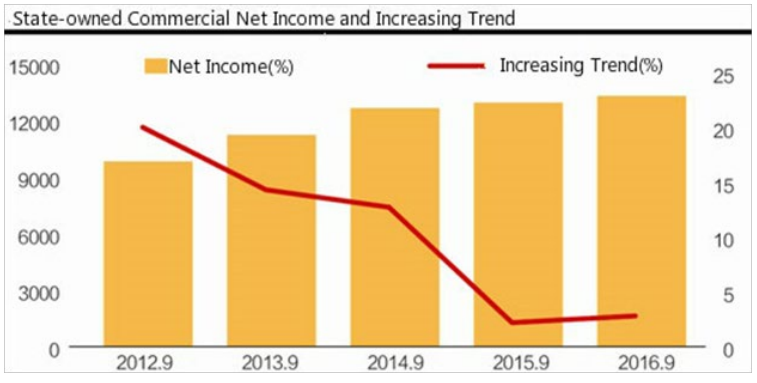

Figure 1.1 China State-Owned Commercial Bank Net Incomes and Increasing Trend

Source:China's Banking Development Trend Report (2017)

\subsection{Research Objectives}

The main objective of this research is to investigate factors of affecting people choose state-owned commercial banks in China. And this study is conducted to meet and answer the following questions.

1. Does bank service provision influence on Chinese people's decision of China state-owned commercial banks?

2. Does government support influence on Chinese people's decision of China state-owned commercial banks?

3. Does online bank services influence on Chinese people's decision of China state-owned commercial banks?

4. Does bank perceived security influence on Chinese people's decisionof Chinastate-owned commercial banks?

5. Do bank service provision, government support, online bank services and bank perceived security influence on Chinese people's decision of China state-owned commercial banks?

\subsection{Significance of Study}

In this research, from finding out different data and information about stated-owned bank, it not only gives benefit in academic, but also gives contribution in professional practice.

a. For the bank

This research help the statedowned commercial banks clear their own advantages and disadvantages, it is helpful to bank can clear market positioning, satisfying more consumers, and attracting more consumers. It can help banks to improve their service and business, so that it can retain the existing consumer and attract new consumer.

b. For the researchers

The researchers can get more clearly understand about China stated-owned commercial bank and what factors affectconsumers to chose state-owned commercial bank.

c. ForConsumer

This study can help consumer to know China state-owned commercial bank information and choose the bank that they really need.

1.6 Limitation of Study

Effecting people decision in selecting commercial banks has lots of uncertain factors, including different kinds of aspect; so, we cannot analyze everyone in our research. Thus, in this research, the researchers concentrate on the factors that affecting Chinese people's decision on China state-owned commercial banks, like services provision, government support, online bank services, bank perceived security, the location of this research focus on Chinese people that stay in Greater Jakarta area.

\section{LITERATURE REVIEW}

\subsection{Introduction}

This chapter mainly contains the theories about Chinese people's decision on China state-owned commercial banks, bank service provision, Government Support, Online Bank Services, Bank Perceived Security, the dependent variable and independent variable theories from journals, related books, and websites written by the technical writers. Furthermore, the Chapter 2 also analysis the factors influence on Chinese people's decision in selecting stateowned commercial bank in China. 


\subsection{Service Provision}

Service provision is defined as a kind of input by service providers for a business or person resource integration and creation value activities. The role of service provider is a value facilitator to support creation value activities by interactive processes, like face to face service or self-service channels. Banks as a kind of organization plays an important role in society life. Banks is a kind of facilitatingsociety value activity, especially for person and enterprise(Nyman, 2014).

During the past decades, banking industry as a kind of service industries, it has been thoroughly transformed. As the development of information and communication technology, service provision also gets improved.Banks provide millions of banking transactions with different types of facility, and it just needs fewer staff. So far,banks are increasingly providing more efficient service(Tinnilä, 2013).

In China, industrial and commercial bank is mainly engaged in credit business, China Construction Bank takes capital construction investment as its main services,and Bank of China is open to foreign credit, Agricultural Bank of China serves mainly agricultural development and construction; it gradually formed professional banking system with the central bank as the core.Bank services provision is one of the standards of bank image(Zineldin, Bank strategic positioning and some determinants of bank selection, 2017).

\subsection{Government Support}

In the late 1990s, in order to promotedevelopment of China's banking industry, the Chinese government has implemented measures to China banks, especially State-owned commercial bank, like solved huge amount of nonperforming loans, and extended the geographical and business restriction of foreign banks with limitation on foreign ownership.And then, government also conducted favorable legislation in China whole bank industry, such as standard accounting and prudential norms(Jin, Liu, Liu, \& Yin, 2014).

In 2001, since China entered WTO, with the foreign Banks in China's growing competition, China Banking Regulatory Commission permits foreigners to own up to 25 percent of banks in China, and partial privatization also expands to the China state-owned commercial banks. In recent years, regulators encourage Chinese banks to list on stock exchange, it improved external monitoring and discipline bank management (Jin, et al., 2014).

China stay centrally planned economy until 1979; the Chinese financial system operating is a singlebankfinancial system. The People's Bank of China conducts monetary and foreign exchange policy, it is responsible for the foreign reserve management, deposit, China government started a comprehensive banking sector reform, the bank financial systemfocuses on transforming banks into market functioning and profitable institutions, four state-owned commercial Banks is the key of the reform(Edmonds, 2017).

There are two main ways of restructuring in China state-owned commercial banks, one isincreased funding, and the other isreduce the phenomenon of non-performing loans. In addition to the restructuring of the state-owned commercial banks, the government and bank regulators also taking important measures to let go of the banking system, the maximum loan interest rate and deposit interest rate upper limit was cancelled, directional loans share drops, and the capital account opened up gradually, there are China financial performance under the government control(Tan \& Floros, 2012). 


\subsection{Online Bank Services}

In order to adapt market competition, and save setup costs, traditional stateowned commercial banks conducted the policy of enhancing the possibilities of their online services. At present, as the continuous development of Internet and information technology, the nature of banks business is changing rapidly, which has been widely recognized. The online bank services already become a universal and popular phenomenon all over the world. It have currently being a part of the modern commercial environment, online banking can be understood as banks provide information or service by computeror mobile phone with internet. It is a combination of conventional banking and web technology. The service delivery channel has high economic and marketing benefits characteristics. It increasingly patronized by banking industry in worldwide(Levy, 2014).

Most of China bank already provides online banking services,including small and medium-sized banks. These years, mobile banking in developing stage, Bank of China, Industrial and Commercial Bank of China and China Merchants Bank already implement the E-bank service, which has several advantages for consumers.Firstly, it has high safety of people's funds. Second, the service can be operated all time that you want, it don't have time limitation and no need service charge. Third, the operating time is fast. There are several kinds of online bank services: Transfer online - people just operate their mobile phone to finish transfer, no need go to bank or ATM, it is convenient. E-bill, people can check bank card bill on their mobile phone by online bank services, it can save time. Online Payment - people can pay for something by their mobile phone, the receiver can receive payment instantly(Laforet \& $\mathrm{Li}$, 2015).

\subsection{Bank Perceived Security}

Security defined the safety offeredand keeps away from danger and harm, perceived security is people believe their sensitive information can be transmitting securely. Bank perceived security is people's perceptions of financial transactions securely, and keeping confidentiality of their personal information in banking system.Security offered by banks gets people's attention, because they are increasingly concerned abouthow bank protects people's personal information. For example, bank transparency can improve bankreliability. In order to protect the excessive profits, China banks present insufficient incentives to disclose true operation information. With the competition increasing, higher level of transparency become necessary to attract Chinese people in China bank industry(Esterik-Plasmeijer \& Raaij, 2017).

Some consumers would consider bank transaction security, reputation and performance have financial stability or not.When selecting a bank, comparing with same kinds of commercial bank, the bank which is more secured would have more advantages. Some researchers indicated that bank perceived security is secured; the bank would acquire trust and confidence from consumers(Wee G. , Shie, Cong, Ying, \& Hou, 2015). When the degree of China state-owned commercial banksperceived security is higher, the probability of Chinese people chooses state-owned commercial bank would be higher.

\subsection{Chinese People's Decision}

The consumer's make-decision process is a journey that evolving to more circular, the main process including Preliminary thinking - it includescollectsinformation; make value judgement on the basis of data 
and facts. Active evaluation - it means people identifies the various solutions or approaches after having a clear understanding of the issue. Closed when consumers choose some specific brand, it related to people's second purchase (Yang, 2012).

There are four steps of consumer's decision journey:

First step: The consumers consider choosing brand by combining brand perceptions with self-requirement.

Second step: Consumers evaluate brand by their subjective consciousness and others, like advertising.

Third step: The consumers choose a brand.

Fourth step: The consumers evaluate the brand or other by their ownexperience and do the next decision

People's choices of banks embody bank products or services value lies. Present state-owned commercial banks offer more and better consumerservice by developing multiple approaches, because people often do not rely on one bank or a kind of service. However, with the increase of small and medium-sized banks and the improvement of financial service quality, peoplechoose different channels based on different scenarios. There are some main factors that affect people's choice of commercial banks, such as services provision, government support, online bank services and bank perceived security(Zhang, Dong, \& Zhu, 2012).

\subsection{Previous Researches}

In the past research, there are also some studies about what factors affect people to choose state-owned commercial bank.Through data collection and data analysis, it was determined which factors were the most important. The following table shows previous authors, studies, variables and conclusions:

Table 2.1. Factors of Affecting Chinese People's Decision

\begin{tabular}{|c|c|c|c|c|}
\hline NO & $\begin{array}{c}\text { Previous } \\
\text { Researchers }\end{array}$ & $\begin{array}{c}\text { Title of } \\
\text { Research }\end{array}$ & Variable & Conclusion \\
\hline 1 & $\begin{array}{l}\text { Kara Chan, } \\
\text { Lennon } \\
\text { Tsang\&Jie Chen } \\
(2017)\end{array}$ & $\begin{array}{l}\text { Marketing Bank } \\
\text { Services To } \\
\text { Youth In China }\end{array}$ & $\begin{array}{l}\text { X1.Service } \\
\text { Provision } \\
\text { X2.Staff attitude } \\
\text { X3.Physical } \\
\text { environment }\end{array}$ & $\begin{array}{l}\text { As the competition in China's banking industry is getting more } \\
\text { and more intense, financial services face some challenges, } \\
\text { financial products are often complicated, and then, evaluating } \\
\text { the quality of financial services is hard to have a standard. } \\
\text { Sometimes, consumers cannot understand them fully. China } \\
\text { state-owned commercial banks try to improve its own services } \\
\text { based on people's need. }\end{array}$ \\
\hline 2 & Leong H. Liew & $\begin{array}{l}\text { A State } \\
\text { Enterprise } \\
\text { In China's } \\
\text { Capitalist } \\
\text { Transformation: } \\
\text { The Bank of } \\
\text { China }\end{array}$ & $\begin{array}{l}\text { X1.Government } \\
\text { Support } \\
\text { X2. Capital Chain }\end{array}$ & $\begin{array}{l}\text { In this study, it research China government support and policy } \\
\text { to China SOCBs, like BOC enjoy state support and operate in } \\
\text { an oligopolistic banking sector dominated by it and its three } \\
\text { major competitors, which are also SOCBs.The end of central } \\
\text { planning and reform to the governance of SOCBs has enlarged } \\
\text { its feasible set of strategies and tactics. }\end{array}$ \\
\hline 3 & $\begin{array}{l}\text { May Wang, } \\
\text { Stella Cho \&Trey } \\
\text { Denton (2017) }\end{array}$ & $\begin{array}{l}\text { The Impact of } \\
\text { Personalization } \\
\text { and } \\
\text { Compatibility } \\
\text { WithPast } \\
\text { Experience } \\
\text { On E-Banking } \\
\text { Usage }\end{array}$ & $\begin{array}{l}\text { X1.Online Bank } \\
\text { Services } \\
\text { X2.E-bank } \\
\text { Performance } \\
\text { Expectancy } \\
\text { X3.Compatibility } \\
\text { X4.Personalization }\end{array}$ & $\begin{array}{l}\text { In China, almost all banks provide e-banking services, } \\
\text { but it is still in initial stage, of course, China state-owned } \\
\text { commercial banks have degree of personalization, in order to } \\
\text { increase usage of e-banking for people and china state-owned } \\
\text { commercial banks focus on the diffusion and adoption of } \\
\text { e-banking. }\end{array}$ \\
\hline 4 & $\begin{array}{l}\text { Esterik-Plas } \\
\text { Meijer \& Raaij } \\
(2017)\end{array}$ & $\begin{array}{l}\text { Bank System } \\
\text { Trust, Bank } \\
\text { Trust, and Bank } \\
\text { Loyalty }\end{array}$ & $\begin{array}{l}\text { X1.Bank perceived } \\
\text { security } \\
\text { X2.Banking } \\
\text { system trust } \\
\text { X3. Loyalty }\end{array}$ & $\begin{array}{l}\text { In general, for consumer relationship, trust is important for } \\
\text { consumer-bank relationship, firstly, bank trust facilitates } \\
\text { transactions with consumers, China State-owned banks are } \\
\text { committed to increasing trust, a high level of state-owned } \\
\text { commercial bank trust attract people. }\end{array}$ \\
\hline
\end{tabular}




\subsection{Research Gaps}

Chan, Tseng\& Chen (2017) indicated the bank market tend to innovate, Chinese people need various banking services and banks already provide different kinds of services to satisfy consumers, including China bank card and banking accounts for receiving salaries, housing mortgage loan, local and overseas consumption credit cards, personal loans for investment products and purchase expensive items.

Liew (2012) investigated the effecting factors for people to China state-owned commercial banks. Chinastate-owned commercial banks as a kind of China state-owned enterprise get government support and financial support to develop them.Inthe developing process, government policy promotes China stateowned commercial banks to perfection system gradually. For individuals, China government conducted financial policy, like the loan system for college students' entrepreneurship.

Wang, Cho \& Denton (2017) points outthat online bank service is one of the most important variables influenceconsumer'schoices, includingconsumer services and online banking facilities. Consumers prefer convenience when they use E-bank which gives them quick access to the bank service.

According to Esterik-Plasmeijer\&Raaij (2017),there are many factors that can influence the choice of commercial banks by consumers. One of the factors is bank perceived security; it is a kind of performance of safety feeling. The previous researcherspoints out that bank trust reflect asassurance of confidentialityand stability of banking infinancial transaction. This implies that bank trust includes both the security at the bank and the safety feeling.

\subsection{Theoretical Framework}

This theoretical model contains independent and dependent variables. The following are the theoretical model:

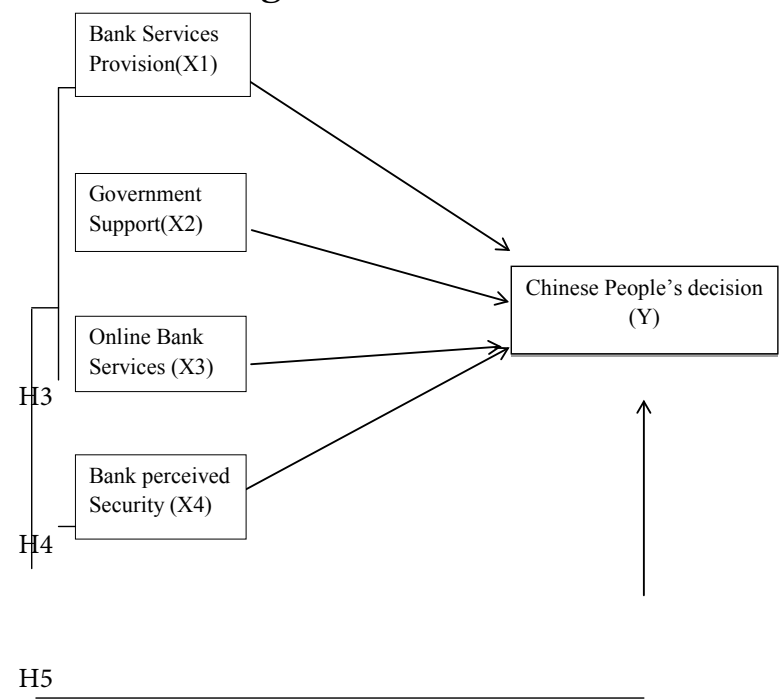

Figure 2.1 Research TheoreticalModels

Source: From Previous Study Summary and Adjustment (2017)

There are four dominant factors most influence on people to choosestate-owned commercial banks, The theoretical model in Figure 2.1 contains four independent variables and one dependent variable, The four independent variables include: $\mathrm{X} 1$ is services provision, $\mathrm{X} 2$ is China government support, $\mathrm{X}_{3}$ is online bank services, $\mathrm{X}_{4}$ isbank perceived security. The dependent variable is the Chinese people's decision on China state-owned commercial banks as Y.

\subsection{Hypothesis}

In order to make the problem authenticity proved, assumptions used in group speculation as a survey method, the researchers test hypothesis and find theoretical knowledge to support the evidence.

Based on the independent variables in this research, there are four hypotheses in this study.

Ho1:Bank service provision has no impact onChinese people's decision of 
State-owned commercial banks.

Ha1:Bank service provision hassignificant impact onChinese people's decisionof China state-owned commercial banks.

Ho2: The governmentsupport notaffect Chinese people's decision peopleof China state-owned commercial banks.

Ha2:The governmentsupportaffect Chinese people's decisionof China stateowned commercial banks.

Ho3:Online bank services not influence Chinese people'sdecisionof China state-owned commercial banks.

Ha3: Online bank servicesinfluence Chinese people'sdecision of Chinastateowned commercial banks.

Ho4:Bank perceived securityhave no significant influence on Chinese people's decisionof China state-owned commercial banks.

Ha4: Bank perceived securityhave a significant influence on Chinese people's decisionof China state-owned commercial banks.

Ho5: Bank service provision, government support, online bank services and bank perceived security have no significant influence on Chinese people's decisionof China state-owned commercial banks.

Ha5: Bank service provision, government support, online bank services and bank perceived security havea significantinfluence on Chinese people's decisionof China state-owned commercial banks.

\section{METHOD}

\subsection{Research Framework}

The research mainly investigates the factors that affecting people choose China state-owned commercial banks. These years, China banks industry develops fast. As the number of small and medium-sized banks increases,
China state-owned commercial banks face intense competition. It's important to find factors that affecting Chinese people's decision on China state-owned commercial banks, service provision, government support, online bank services, bank perceived security are the factors that needed to be considered.

\subsection{Hypothesis}

In order to make the problem authenticity proved, assumptions used in group speculation as a survey method, the researchers test hypothesis and find theoretical knowledge to support the evidence.

Based on the independent variables in this research, there are four hypotheses in this study.

Ho1: Bank service provision has no impact on Chinese people's decision of State-owned commercial banks.

Ha1:Bank service provision hassignificant impact on Chinese people's decision of China state-owned commercial banks.

Ho2: The government support notaffect Chinese people's decision peopleof China state-owned commercial banks.

Ha2:The government supportaffect Chinese people's decisionof China stateowned commercial banks.

Ho3: Online bank services not influence Chinese people's decisionof China state-owned commercial banks.

Ha3: Online bank services influence Chinese people's decision of Chinastateowned commercial banks.

Ho4:Bank perceived securityhave no significant influence on Chinese people's decisionof China state-owned commercial banks.

Ha4: Bank perceived securityhave a significant influence on Chinese people's decisionof China state-owned commercial banks.

Ho5: Bank service provision, 
government support, online bank services and bank perceived security have no significant influence on Chinese people's decisionof China state-owned commercial banks.

Ha5: Bank service provision, government support, online bank services and bank perceived security have a significant influence on Chinese people's decisionof China state-owned commercial banks.

Table 3.1: Operational Definitions of Variables

\begin{tabular}{|c|c|c|c|}
\hline NO & Variable & Definition & Indicator \\
\hline \multicolumn{4}{|c|}{ Independent Variables } \\
\hline NO & $\begin{array}{c}\text { Previous } \\
\text { Researchers }\end{array}$ & $\begin{array}{c}\text { Title of } \\
\text { Research }\end{array}$ & Variable \\
\hline 1 & $\begin{array}{l}\text { Service } \\
\text { provision }\end{array}$ & $\begin{array}{l}\text { Service provision } \\
\text { is a kind of input } \\
\text { that service } \\
\text { provider for } \\
\text { consumer resource } \\
\text { integration and } \\
\text { create value } \\
\text { activities, it } \\
\text { including face to } \\
\text { face interactionsor } \\
\text { self-services } \\
\text { channels (Nyman, } \\
\text { 2014). }\end{array}$ & $\begin{array}{l}\text { 1. Financial } \\
\text { services } \\
\text { providers } \\
\text { 2. Face to face } \\
\text { services } \\
\text { 3. } \begin{array}{l}\text { Self-service } \\
\text { channels }\end{array} \\
\text { 4. Efficient } \\
\text { services }\end{array}$ \\
\hline 2 & $\begin{array}{l}\text { Government } \\
\text { Support }\end{array}$ & $\begin{array}{l}\text { Government } \\
\text { support for } \\
\text { banks affects } \\
\text { the willingness } \\
\text { of market bear } \\
\text { banks risk by } \\
\text { the provision of } \\
\text { specific or implicit } \\
\text { guarantees } \\
\text { (Brandao- } \\
\text { Marques, Correa, } \\
\text { \& Sapriza, 2013). }\end{array}$ & $\begin{array}{l}\text { 1. Promote } \\
\text { development } \\
\text { 2. Favorable } \\
\text { legislation } \\
\text { 3. Chinafinancial } \\
\text { performance }\end{array}$ \\
\hline 3 & $\begin{array}{l}\text { Online Bank } \\
\text { Services }\end{array}$ & $\begin{array}{l}\text { Online bank } \\
\text { servicesis } \\
\text { bank provide } \\
\text { information } \\
\text { or services to } \\
\text { consumers by } \\
\text { internet-oriented } \\
\text { devices, such as } \\
\text { computer, mobile } \\
\text { phone (Levy, } \\
\text { 2014). }\end{array}$ & $\begin{array}{l}\text { 1. Technology } \\
\text { 2. Service charge } \\
\text { 3. High safety } \\
\text { 4. E-bank } \\
\text { services }\end{array}$ \\
\hline 4 & $\begin{array}{l}\text { Bank } \\
\text { Perceived } \\
\text { Security }\end{array}$ & $\begin{array}{l}\text { Perceived security } \\
\text { defined as bank } \\
\text { information } \\
\text { security, protective } \\
\text { mechanisms }\end{array}$ & $\begin{array}{l}\text { 1. Securityoffered } \\
\text { 2. Reliability } \\
\text { 3. Personal } \\
\text { information } \\
\text { 4. Financial } \\
\text { stability }\end{array}$ \\
\hline
\end{tabular}

like encryption, authentication, intrusion detection and etc; andthe financial services is enough safe to give people secure feeling (Mekovec \& Hutinski, 2012).

Dependent Variables As the bank industry environment is gradually getting more competitive, banks in market compete for consumers, bank can improve competitiveness 1. Consumer's by understand decision consumer behavior 2. Consumer and demands of service the bank products 3 . Financial and services, like service quality what people's bank preferences when they choose banks, why people choose state-owned commercial banks for their services or products (Wee, Shie, Cong, Ying \&Hou, 2015).

\subsection{Operational Definition 3.4 Research Instrument}

Research instrumentare tools for data collecting, it is a part of research. This research is using questionnaire mainly. No matter what method that used to collect data in research, it must to have narrow examination(Annum, 2017).

\subsubsection{Research Method}

Quantitative research is an exact approach for test objective theories by examining the relationship among variables.Quantitativeresearchgets data from a large group of respondents. It always used by the form of numbers or that can be transported into numbers immediately (DeFranzo, 2012).

Qualitative research is a kind of exploratory study.Itcollects data by unstructured or semi-structured techniques to understand underlying 
reasons, opinions and motivations, the sample size always small(DeFranzo, 2012).Researchers use quantitative methods by the questionnaire for data. Thequestionnaire contains two parts. Firstly, it focuses on the population to achieve the research objective. The other one is respondents to agree or disagree with questions to get the result of factors that affecting people choose state-owned commercial banks using a five-point Likert scale ranging from "strongly disagree" to "strongly agree".

\subsubsection{Data Analysis Method}

\subsubsection{Validity Test\& reliability Test}

\section{Validity Test:}

Validity means data's accuracy and truth. Validity is one of the most important standards for testing quality; it is closely related to the expected focus of the test. In a research, if the researchers choose questionnaire as the research instrument, in order to enhance the accuracy of questionnaire statement, the questionnaire must be able to measure what it is supposed to be measured(Heffner, 2014).

\section{Reliability Test:}

Reliability means the consistency of results from research test.Reliability coefficient is a test of determining statistic reliability. This coefficient not only represents correlation, it measures the direction and intensity of relationship between several variables.It includes three main approaches, which are testretest reliability, parallel forms reliability and inter-rater reliability.

Coefficient Alphaformula is a kind of approach to test reliability; this formula can check whether the variable in the research is reliable or not(Heffner, 2014). $\mathrm{k}=$ the totality of test

$\Sigma=$ sum

$\mathrm{p}=$ the ratio of the test takers who pass

$\mathrm{q}=$ the ratio of test takers who fail

$\sigma 2=$ the variation of all test

From the calculation result, if $\alpha \geq 0.9$, the internal consistency is reliable. Ifo. 7 $\leq \alpha<0.9$, means the internal consistency is good. If $0.6 \leq \alpha<0.7$, means the internal consistency isacceptable. If $0.5 \leq$ $\alpha<0.6$, means the internal consistency is poor. If $\alpha<0.5$, the internal consistency is rejected.

\subsubsection{Description Analysis}

Description analysis is used for checking the degree of relationship between independent variables and dependent variable by mean and standard deviation of each variable.

\section{Mean}

Mean is the average of a set of data that measured variables, itrepresents the data's central tendency of the values. In the data measurement, mean value need to be measured(Lee, In, \& Lee, 2015). The statistical formula as follows:

$$
\begin{aligned}
& \text { Where: } \quad \overline{\mathbf{x}}=\frac{\sum \mathrm{x}_{\mathrm{i}}}{\mathrm{n}} \\
& \mathrm{x}=\text { Sample mean } \\
& \Sigma=\text { "Add up" } \\
& \mathrm{xi}=\text { Total x-values" } \\
& \mathrm{n}=\text { Number of sample items }
\end{aligned}
$$

\section{Standard Deviation}

In a research, Standard deviation is a kind of data dispersion in normal distribution, it point out the accurately of the mean represents the data of sample(Lee, In, \& Lee, 2015).The following is the sample standard deviation formula:

Where:

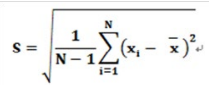

$$
\text { Where: } r_{\alpha}=\left(\frac{k}{k-1}\right)\left(1-\frac{\Sigma \sigma^{2}}{\sigma^{2}}\right)
$$


$\mathrm{S}=$ Standard deviation of sample

$\mathrm{N}=$ Sample number

$\mathrm{N}-1=$ Bessel's correction or degree of freedom

$\mathrm{x}=$ each value in the sample

$\mathrm{x}=$ Sample mean

\subsubsection{Classical Assumption}

The following are four common classical assumption tests, which areNormality test,Multicollinearity test, Heteroscedasticity test, and Autocorrelation test. Normality test focus oncheck whether the data is distributed normally, in this research, it used and done by SPSS statistical software. Multicollinearity testapplied to independent variables' correlation. In order to prove the relationship between independent variable and dependent variables, it always use tolerance $(\mathrm{T})$ and variance inflation factor (VIF) value test, which VIF should be more than 0.1 and less than 10. In the research, if the test more than standard, means the research data is failed.Heeteroscedasticity test always use scatter diagram. If the graph don't have particular pattern in the research, the data can be defined randomly scattered without patterning. The Autocorrelation testalways use Durbin-Watson value to examine data, the Durbin-Watson value is $0<\mathrm{X}<4$, in this scope, it means the research data don't have autocorrelation problem ((Ainiyah, Deliar, \& Virtriana, 2016).

\subsubsection{Hypothesis Test}

\section{Multiple Linear Regressions}

Multiple linear regression analysis was used to ensure whether the independent variable has an effect on the dependent variable, SPSS as Statistical calculations in this research.

\footnotetext{
$Y=\beta \_0+\beta \_1 \quad X \_1+\beta \_2 \quad X \_2+\beta \_3 \quad X \_3+\beta \_4$ $\mathbf{X} \_+\mathbf{\varepsilon}$

Where,

$\mathrm{Y}=$ the people's decision on State-
}

owned Commercial bank in china, it is the dependent variable

$\beta=y$-intercept (value of $\mathrm{Y}$ when $\mathrm{X}=\mathrm{o}$ )

$\beta 1, \beta 2, \beta 3, \beta 4$, = the coefficient of each relevant independent variables;

$\mathrm{X}_{1}, \mathrm{X} 2, \mathrm{X}_{3}, \mathrm{X}_{4}$, represents Service Provision, government support, bank services online, bank perceived security.

$\varepsilon=$ possible error

\section{T-Test}

In statistics, t-tests are a kind of hypothesis test that ascertain the impact of independent variables towards the dependent variable in multiple regression models(Frost, 2016). By comparing each independent variable value of significant $\mathrm{t}$ with significant standard $\alpha=0.05$.

This is the T-Test formula:

Where:

$$
t=\frac{\mathbf{b}_{\mathrm{j}}-\beta_{\mathrm{j}}}{S \mathbf{b}_{\mathrm{j}}}
$$

$\mathrm{t}=$ Distribution of statistic test

bj $=$ Sample

$\beta \mathrm{j}=$ population

Sbj $=$ Regression coefficient standard error

Hypothesis: If significance $t<0.05$, Ho is rejected,it means that independent variables have significant influence on the dependent variable, if significance t>0.05, it means independent variables have no significant influence on the dependent variable.

\section{F-Test}

F-test is a kind of statistical method to check whether the research variables are independent, it focuses on the independent variables and dependent variable has significant influence or not(Frost, 2016).

This is the F-Test formula:

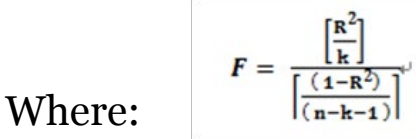




$$
\begin{aligned}
& \mathrm{F}=\mathrm{F} \text { distributionstatistic test } \\
& \mathrm{R} 2=\text { determination coefficient } \\
& \mathrm{k}=\text { independent variables number } \\
& \mathrm{n}=\text { samplesnumber }
\end{aligned}
$$

Ho: $\beta 1=\beta_{2}=\beta_{3}=\beta_{4}$, when the significance of $\mathrm{F}>0.05$, then result will accept Ho

Ha: at least when $\beta \mathbf{i} \neq 0$, when the significance of $\mathrm{F}<0.05$, then result will reject Ho

The value of significance that used in this study is $\alpha=0.05$. If the F-test value is greater than the value of significance, Ho is accepted. And if the F-test value is less than the value of significance, Ho is rejected.

\section{Coefficient of Determination} (R2)

Coefficient of determination explains how much of the response dependent variable that can be caused or explained by the independent variables. If the value of $\mathrm{R} 2$ is high, it shows the regression relationship is relatively high. The higher the value, the better variables fit.

\subsection{Sampling Methodology 3.5.1 Research Population}

Generally, the research population always a large amounts collection of individuals or objects, because of the large sizes of populations, in the research population, it is unrealistic for researchers to measure every individual, it need high expend and lots of time(Creswell, 2014). The population (individuals or objects) areselected by researchersthat have similar characteristics accord with the research objective, so, a suitable population plays an important role in the research.

\subsubsection{Size of Sample}

Sample size is the number of individual samples or the number of observations used in a research or survey(Zamboni, 2017). Slovin formula always used to calculatehow many respondents are selected, it can ensure that every Chinese get equal opportunity to answer the questionnaire.

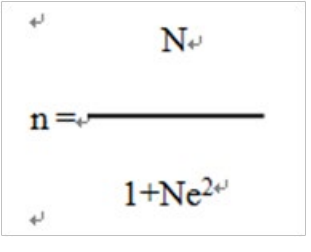

$$
\begin{aligned}
& \text { Where: } \\
& \mathrm{n}=\text { Size of sample } \\
& \mathrm{N}=\text { Population } \\
& \text { e= Error margin } \\
& \text { Calculation: } \\
& \mathrm{n}=568 /\left(1+568^{*} 0.05^{2}\right)=235 \\
& \mathrm{n}=235
\end{aligned}
$$

Total size of sample: $235+30=265$

Therefore, the questionnaire would be spread to 265 respondents who involved in the researchbased on the researchers' judgement, including 235 respondents and 30 respondents for pre-test, fot this study.

\subsubsection{Sampling Technique}

In the research, the sample is simply a part of the population, because the researchers cannot measure all of the individuals in a given population, saving lots of time and money is characteristics that researchers prefer sampling techniques. And then, in the research, the sample is representative of the population and has appropriate size to ensure statistical analysis(Creswell, Research design, 2013). The population of this research would be the Chinese that stay in Greater Jakarta area in Indonesia and have life or work experience.

\subsubsection{Data Collection Method}

Due to the researchers use questionnaire that made by them to get result and collect data, the reliability and validity have to get verification.

In this research, the number of 
respondents is limited, the target respondents is Chinese people that stay in Greater Jakarta area in Indonesia. There are two ways to gather the result and collect data. One is manually, questionnaire that made by Google forms, and second is spreadby social platform, like WhatsApp, WeChat and QQ chatting. Of course, the researchers also use original data and secondary data to support this study, and the secondary data may from journals and banks annual reports, and then, the collected data would be edit and input into Microsoft Excel.

\section{ANALYSIS AND DISCUSSION}

\subsection{Pre-Test Result}

In order to ensure all the statements in the questionnaire are reliable and valid in this research, the researchers selected 30 respondents' data for Pre-test before spreading questionnaire and analyzing data.

\subsubsection{Validity Test}

In the Pre-Test, the total sample size is 30 and the $\mathrm{df}$ (degree of freedom) is 28 , the result of $\mathrm{R}$ is 0.361 from the list of $\mathrm{R}$-able. If $\mathrm{R}$ is more than 0.361 , it means the statements of questionnaire are valid; if $\mathrm{R}$ is less than 0.361, the statements of questionnaire are not available.

\begin{tabular}{lcccc}
\multicolumn{5}{c}{ Table 4.1 Validity Test Result } \\
\hline \multicolumn{2}{c}{ Validity } & R-Table & $\begin{array}{c}\text { Corrected } \\
\text { Item Total } \\
\text { correlation }\end{array}$ & Status \\
\hline Services & SP1 & 0.361 & 0.614 & Valid \\
Provision & SP2 & 0.361 & 0.666 & Valid \\
& SP3 & 0.361 & 0.659 & Valid \\
& SP4 & 0.361 & 0.590 & Valid \\
Government & GS1 & 0.361 & 0.795 & Valid \\
Support & GS2 & 0.361 & 0.608 & Valid \\
& GS3 & 0.361 & 0.763 & Valid \\
& OBS1 & 0.361 & 0.779 & Valid \\
Online Bank & OBS2 & 0.361 & 0.748 & Valid \\
Services & OBS3 & 0.361 & 0.689 & Valid \\
& OBS4 & 0.361 & 0.758 & Valid
\end{tabular}

\begin{tabular}{|c|c|c|c|c|}
\hline \multirow{4}{*}{$\begin{array}{l}\text { Bank } \\
\text { Perceived } \\
\text { Security }\end{array}$} & BPS1 & 0.361 & 0.796 & Valid \\
\hline & BPS2 & 0.361 & 0.762 & Valid \\
\hline & $\mathrm{BPS}_{3}$ & 0.361 & 0.758 & Valid \\
\hline & $\mathrm{BPS}_{4}$ & 0.361 & 0.835 & Valid \\
\hline \multirow{3}{*}{$\begin{array}{l}\text { Chinese } \\
\text { people's } \\
\text { Decisions }\end{array}$} & CPD1 & 0.361 & 0.845 & Valid \\
\hline & CPD2 & 0.361 & 0.814 & Valid \\
\hline & CPD3 & GS2 & 0.736 & Valid \\
\hline
\end{tabular}

Source: Constructed in SPSS 20.0 (2018)

According to the Table 4.1, all of the $R$ results of the questionnaire statements more than 0.361 of R-Table,proved all statements of questionnaire are available. Therefore, theresearcherss can use the questionnaire consistently in this research.

\subsubsection{Reliability Test}

\begin{tabular}{cc}
\multicolumn{2}{c}{ Table 4.2TheResult of Reliability } \\
\hline Cronbach's Alpha & N of Items \\
\hline .912 & 18
\end{tabular}

Source: Constructed in SPSS 20.0 (2018)

The researchers test reliability by putting total questions data in SPSS 20.0.In the table of the 4.2, Cronbach's Alpha value of the questionnaire statements is 0.912 , it greater than 0.6 , so the result is reliable.

\subsection{Respondent Identities}

In this research, the researchers collected primary data by distributing questionnaire to Chinese. The questionnaire including people's profile and variable questions. Respondents' profile composed by respondents' nationality, gender, age, monthly income, educational level and already used big four banks in China or not. The researchers already collected data from 265 respondents, as follows:

\subsubsection{Nationality}




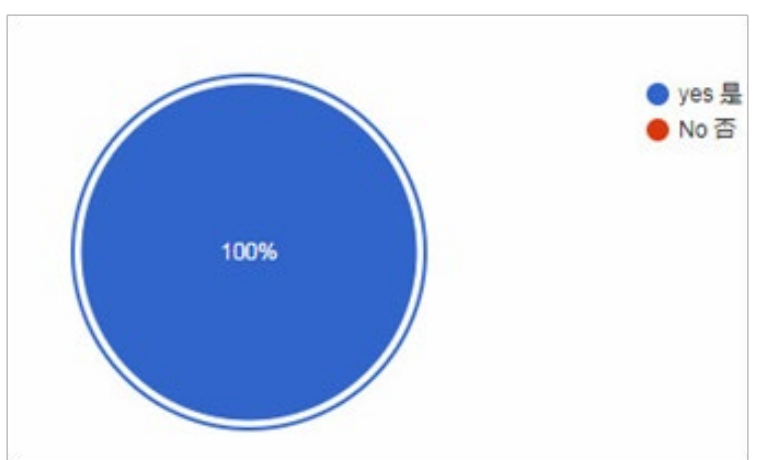

Figure 4.1Pie Chart of Respondents' Nationality

Source: The data from Google Form (2018)

In this research, the survey target is Chinese people that stay in Greater Jakarta area in Indonesia.The pie chart shows the respondents' nationality rate is $100 \%$, and it means all of this 265 respondents are Chinese people.

\subsubsection{Gender}
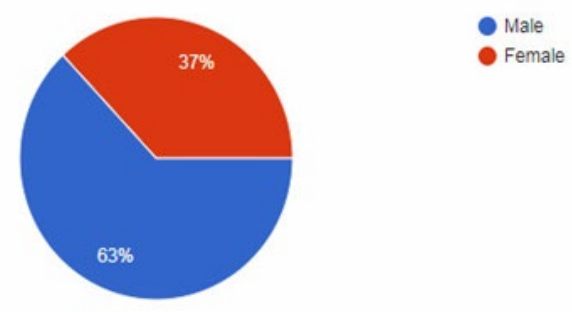

Figure 4.2 Gender Distribution Source: The data from Google Form (2018)

In theGoogle form respondent result, the rate of $37 \%$ respondents isfemale and the rate of $63 \%$ respondents is male. In this research, from the sample of 265 , the number of female respondents is 167 and the number of female respondents is98. The number of male and female respondents is not same, male make up a large proportion.

\subsubsection{Age}

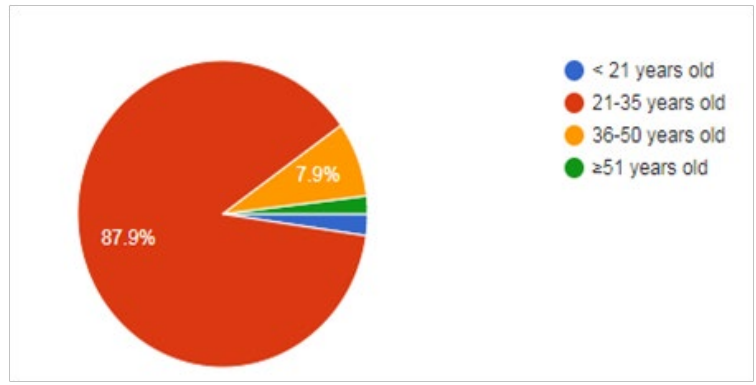

Figure 4.3 Age Distribution

Source: The data from Google Form (2018)

In this 265 respondents, the respondents rate is $2.3 \%$ ( number is 6) under 21 years old, there are $87.9 \%$ (233) respondents are from 21-35 years old,7.9\% (21) respondents are from 3650 years old, and 5 (1.9\%)respondents are older than 51 years old.In a word, most of the respondents are 21-35 years old.

\subsubsection{Monthly Income}

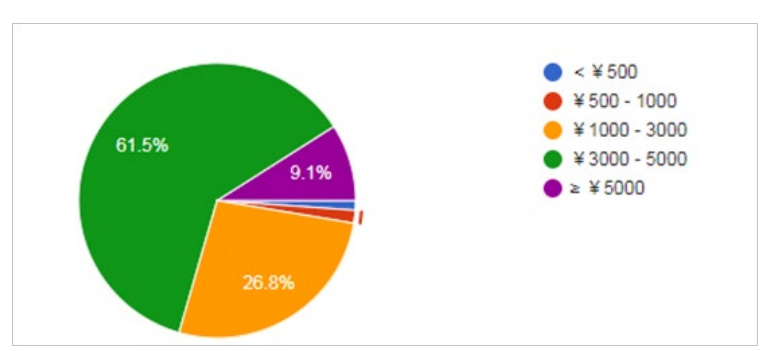

\section{Figure 4.4 Monthly Income Distributions}

Source: The data from Google Form (2018)

The pie chart shows the respondents monthly income, there are $1.1 \%$ (3) respondents monthly income less than 500 RMB (Chinese currency), 1.5\% (4) respondents monthly income are 500 to $1,000 R M B(R p .1$, O00,000- Rp. 2,000,000), $26.8 \%(71)$ respondents monthly income are 1,000-3,000 RMB; $61.5 \%(163)$ respondents monthly income are 3,000-5,000RMB (Rp. 6,000,000 Rp. 10,000,000); 9.1\%(24) respondents monthly income more than 5000 
Siska Purnama Manurung and Chen Ke

RMB (Rp. 10,000,000). In these 265 respondents, the monthly income is 1000-3000 RMBis a large proportion, most of the respondents monthly income stay in 1000-5000 RMB (RP2, 000,000RP10, 000,000) level.

\subsubsection{Education Level}

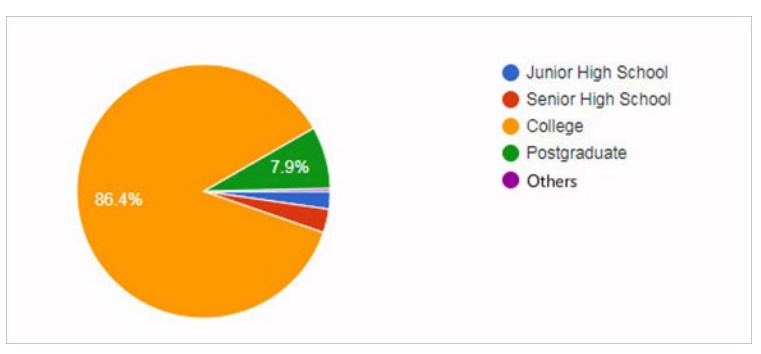

Figure 4.5 Education Level Distributions

Source: The data from Google Form (2018)

The pie chart shows the 265 respondents education level.It shows $2.3 \%$ (6) respondents education level are junior high school, 3\% (8) respondents education level are senior high school, 86.4\% (229) respondents education level are college, the rate of postgraduate respondents is $7.9 \%$ and the number of postgraduate respondents is 21 , and $0.4 \%$ (1) respondents education level is others. In a word, from 265 respondents, the respondents' education level focuses on college.

\subsection{Description Analysis}

\begin{tabular}{lrrrrr}
\multicolumn{5}{c}{ Table 4.3 Descriptive Statistics } \\
\hline N & $\begin{array}{c}\text { Mini- } \\
\text { mum }\end{array}$ & $\begin{array}{c}\text { Maxi- } \\
\text { mum }\end{array}$ & Mean & $\begin{array}{c}\text { Std. } \\
\text { Deviation }\end{array}$ \\
\hline SP1 & 265 & 1 & 5 & 3.79 & .984 \\
SP2 & 265 & 1 & 5 & 3.79 & .999 \\
SP3 & 265 & 1 & 5 & 3.80 & 1.060 \\
SP4 & 265 & 1 & 5 & 4.02 & 1.080 \\
GS1 & 265 & 1 & 5 & 4.17 & .980 \\
GS2 & 265 & 1 & 5 & 4.25 & .817 \\
GS3 & 265 & 1 & 5 & 4.25 & .883 \\
OBS1 & 265 & 1 & 5 & 3.70 & 1.168 \\
OBS2 & 265 & 1 & 5 & 3.78 & 1.191
\end{tabular}

\begin{tabular}{llllll} 
OBS3 & 265 & 1 & 5 & 4.14 & .929 \\
OBS4 & 265 & 1 & 5 & 4.22 & .885 \\
BPS1 & 265 & 1 & 5 & 4.38 & .730 \\
BPS2 & 265 & 1 & 5 & 4.20 & .900 \\
BPS3 & 265 & 1 & 5 & 4.40 & .792 \\
BPS4 & 265 & 1 & 5 & 4.40 & .727 \\
CPD1 & 265 & 1 & 5 & 4.44 & .689 \\
CPD2 & 265 & 1 & 5 & 4.19 & .838 \\
CPD3 & 265 & 1 & 5 & 4.31 & .871 \\
Valid N & 265 & & & & \\
(listwise) & & & & & \\
\hline
\end{tabular}

Source: Constructed in SPSS 20.0 (2018)

In the descriptive statistics table of SPSS, It shows the sample number, minimum, maximum, mean and standard deviation. Chinese people's decision of China state-owned commercial banks (CPD) mean (average value) is 4.44, 4.19 and 4.31, respectively, and the CPD standard deviation is $0.689,0.838$ and 0.871 . In theory of statistics and probability, the lower standard deviation means the data is closer towards the value of expecting. In this research, the standard deviation value of online bank services (OBS)questionnaire statements is $1.168,1.191$ and 0.929 , it more the others independent variables standard deviation value.

\subsection{Classical Assumption 4.4.1 Normality Test}

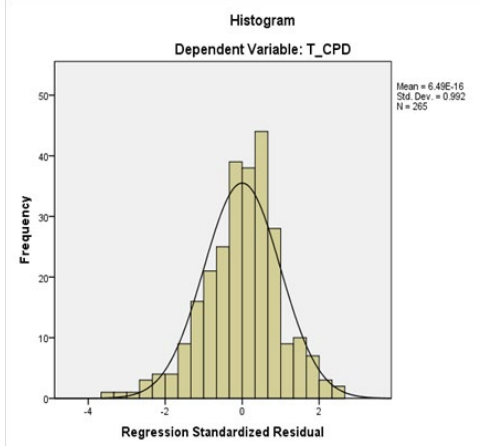

Figure 4.6 Histogram Test

Source: Constructed in SPSS 20.0 (2018) 
In the research, normal distribution data means the data has population representativeness by spreading evenly. In the figure of the histogram, if the figure is symmetrical, the data is normal distribution. If the data skewed to the left, it means the data is positive skewness; if the data skewed to the right, it means the data is negative skewness. Based on the Figure 4.1, most of the data concentrate upon the scope of -2 to 2 , it is normally distributed.

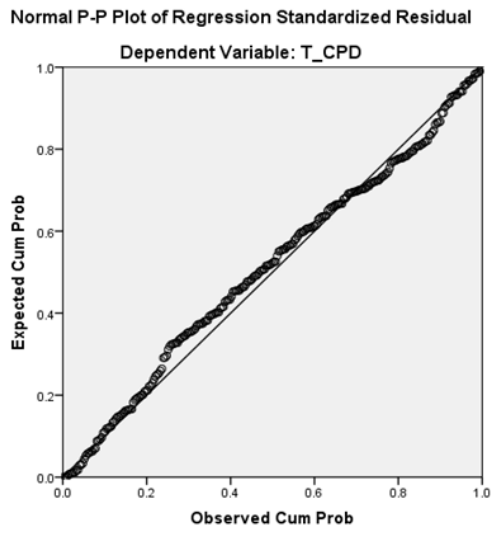

Figure 4.7 P - P Plot Normality Test Source: Constructed in SPSS 20.0 (2018)

According to the figure 4.2, the SPSS output indicate the data spread around the diagonal line closely, some data trend to overlap with the diagonal line, therefore, the data is satisfied with normality distribution.

\subsubsection{Multicollinearity Test}

Multicollinearity test mainly measures variables have high correlation or not in multiple regression, in a research, if the independent variables have a high correlation with each other's, it improved the error level in the regression model. Thus, independent variables correlation shouldn't exist in a good regression model. In the Multicollinearity testing, the researchers can examine the value of Variance Inflation Factors (VIF) and Tolerance, if the value of tolerance $0.01<\mathrm{x}<1$, the value of VIF $0.1<\mathrm{x}<10$, there

\begin{tabular}{|c|c|c|}
\hline & Collinearity & atistics \\
\hline $\begin{array}{l}\text { Model } \\
\text { (Constant) }\end{array}$ & Tolerance & VIF \\
\hline T-SP & .862 & 1.161 \\
\hline T-GS & .853 & 1.173 \\
\hline T-OBS & .804 & 1.244 \\
\hline T-BPS & .819 & 1.222 \\
\hline
\end{tabular}

multicollinearity. Conversely, if the VIF value more than 10, the tolerance value less than 0.10 , it means there is multicollinearity.

Source: Constructed in SPSS 20.0(2018)

Based on the figure 4.3, the total service provision(TSP) tolerance value is 0.862 , the tolerance value of total government support (TGS) is 0.853 , the total online bank services (TOBS) is 0.804 , and the total bank perceived security (TBPS) is o.819. All of the independent variables tolerance value between 0.01 and 1 , it proved the regression model don't have multicollinearity problem.

In the VIF area, the figure 4.3 shows the VIF value of total service provision (TSP) is 1.161, the total government support is 1.173 , the total online bank services is 1.244 , the total bank perceived service is 1.222. All of the independent variables VIF value between 0.1 and 10. Thus, there is no multicollinearity problem.

\subsubsection{Heteroscedasticity Test}

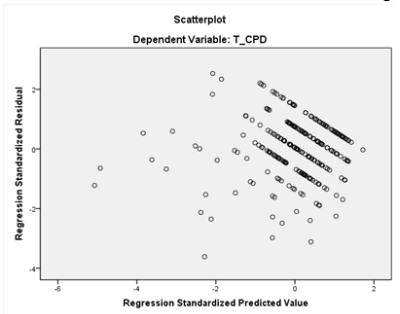

Figure 4.8 Heteroscedasticity Scatterplot

Source: Constructed in SPSS 20.0 (2018) 
Siska Purnama Manurung and Chen Ke

From the SPSS output scatterplot, the Figure 4.3 shows the Heteroscedasticity test by Scatter plot. In the scatterplot, some scatter distribution trend to be near oblique line, on the whole, the scatter distributed around $\mathrm{O}$, so the research data distributed randomly without some special patterning, there is no heteroscedasticity problem.

\subsubsection{Autocorrelation Test}

Autocorrelation test always be done by the Durbin-Watson value(DW). If theDurbin-Watson value(DW) is between 0 and 4 , it means the data no auto correlation problem.

\begin{tabular}{|c|c|c|c|c|c|}
\hline Model & $\mathbf{R}$ & $\begin{array}{c}\mathbf{R} \\
\text { Square }\end{array}$ & $\begin{array}{l}\text { Adjusted } \\
\text { R Square }\end{array}$ & $\begin{array}{c}\text { Std. } \\
\text { Error } \\
\text { of the } \\
\text { Estimate }\end{array}$ & $\begin{array}{l}\text { Durbin- } \\
\text { Watson }\end{array}$ \\
\hline 1 & $.654^{a}$ & .428 & .419 & 1.42358 & 2.128 \\
\hline
\end{tabular}

Source: Constructed in SPSS 20.0 (2018)

Based on the table 4.8, according to the SPSS output model summary, the result of the Durbin-Watson(DW) is $2.128,0<2.128<4$, the result conform to the Durbin-Watson value(DW)standard, there is no autocorrelation problem.

\subsection{Hypothesis Test}

\subsubsection{Multiple Regression Analysis}

One or several predictor variable $\mathrm{X}$ is used to model the value of dependent variable $\mathrm{Y}$ in multiple linear regressions, there is one or more factors that affect the dependent variable, and the multiple regression analysis mainly described how a dependent variable $\mathrm{Y}$ depends on one or several predictor variable $\mathrm{X}$ (Bremer, 2012).

Table 4.6 Coefficientsa

\begin{tabular}{lcccccc}
\hline \multirow{2}{*}{ Model } & \multicolumn{2}{c}{$\begin{array}{c}\text { Unstandardized } \\
\text { Coefficients }\end{array}$} & $\begin{array}{c}\text { Standardized } \\
\text { Coefficients }\end{array}$ & \multirow{2}{*}{ Sig. } \\
\cline { 2 - 5 } & B & Std. Error & Beta & & \\
\hline (Constant) & 2.399 & .872 & & 2.751 & .006
\end{tabular}

\begin{tabular}{cccccc} 
T_SP & -.033 & .032 & -.052 & -1.029 & .304 \\
T_GS & .148 & .051 & .147 & 2.884 & .004 \\
T_OBS & .093 & .029 & .166 & 3.166 & .002 \\
T_BPS & .443 & .043 & .529 & 10.197 & .000 \\
\hline \multicolumn{5}{c}{ a. Dependent Variable: T_CPD }
\end{tabular}

Source: Constructed in SPSS 20.0 (2018)

In multiple regression analysis, the confidence intervals level is 95\%, thus, the maximum error is 0.05 (5\%). Comparing the result of predictor independent variable with 0.05 , if the result is equal to 0.05 or less than 0.05 , it means the predictor independent variable is significant, if the result more than 0.05, it means the predictor independent variable no significance.

In this research, according to the table 4.9, SPSS output coefficients shows the result of service provision (X1) is 0.304 , the government support (X2) result is 0.004 , the result of online bank services (X3) and the bank perceived security (X4) are 0.002 and 0.000 respectively. The result of $\mathrm{X}_{1}$ more than 0.005 , and the $\mathrm{X}_{2}, \mathrm{X}_{3}$ and $\mathrm{X}_{4}$ are less than 0.05 , the researchers done the following table.

Table 4.7 Significance Table

\begin{tabular}{ccc}
\hline $\begin{array}{c}\text { Independent } \\
\text { Variables }\end{array}$ & Significance Value & $\begin{array}{c}\text { Standard Value } \\
\text { of o.o5 }\end{array}$ \\
\hline Service Provision & 0.304 & Not Significance \\
Government Support & 0.004 & Significance \\
Online Bank Services & 0.002 & Significance \\
Bank Perceived & 0.000 & Significance \\
Security & & \\
\hline
\end{tabular}

Source: Constructed by Researchers (2018)

Based on the table 4.9 and 4.10 , the service provision (X1) is not significance, the government support (X2), online bank services $\left(\mathrm{X}_{3}\right)$ and bank perceived security (X4) is significance. Therefore, in this research, the following is the multiple regression line equation:

$$
\mathrm{Y}=0.147 \mathrm{X}_{2}+0.166 \mathrm{X}_{3}+0.529 \mathrm{X}_{4}+\varepsilon
$$


In the multiple regression line equation above, Service provision (X2) has an impact of 0.147 on the Chinese people's decision on China stateowned commercial banks (Y), under the condition of other factors keep unchanged, if $\mathrm{X} 2$ increases or decreases one point, the dependent variable $\mathrm{Y}$ would increase or decrease 0.147 .

In the multiple regression line equation above, the online bank services (X3)has an impact of 0.166 on the Chinese people's decision on China state-owned commercial banks (Y), under the condition of other factors keep unchanged, if $\mathrm{X}_{3}$ increases or decreases one point, the dependent variable $\mathrm{Y}$ would increase or decrease 0.166.

The regression coefficient value of bank perceived security (X4) is 0.529 on the Chinese people's decision on China state-owned commercial banks (Y), under the condition of other factors keep unchanged, if $\mathrm{X}_{4}$ increases or decreases one point, the dependent variable $\mathrm{Y}$ would increase or decrease 0.529 .

\subsubsection{T-Test}

T-test is a kind of hypothesis test in statistics, T-test get T-value by inputting and analyzing sample data in SPSS, though comparing each independent variable significance valuewith the significancelevel(0.05). If thesignificance value equal to $o$, it means the data results is null hypothesis, if the significance valueget closer to 0 , it means the data result have less significant differences. If the independent variable significance valueis less than the 0.05 , it meansthe independent variable is significant(Frost, 2016).

Inthetable4.10, theresearchersalready did the analysis and result whether each independent variable (X) has a significance effect on dependent variable (Y).

Service provision $(\mathrm{X} 1)$ : the significance valueis 0.304 , since the 0.304 more than 0.05 , the Ha1 is rejected and the Ho1is accepted. The service provision (X1) has not significant impact on the Chinese people's decision (Y) on China stateowned commercial banks.

Government support (X2): the significance valueis 0.004 , since the $0.004<0.005$, the Ha2 is accepted and the Ho2 is rejected. Thegovernment support (X2) has a significance influence of the Chinese people's decision (Y) on China state-owned commercial banks.

Online bank services $\left(\mathrm{X}_{3}\right)$ : the result of $\mathrm{T}$ is 0.002 , since the $0.002<0.005$, the Ha3 is accepted and the Ho3 is rejected. The online bank services (X3) has a significance influence of the Chinese people's decision (Y) on China stateowned commercial banks.

Bank perceived security $\left(\mathrm{X}_{4}\right)$ : the $\mathrm{T}$ result is 0.000 , since the $0.000<0.005$, the $\mathrm{Ha}_{4}$ is accepted and the $\mathrm{Ho}_{4}$ is rejected. The bank perceived security (X4) has a significance influence of the Chinese people's decision (Y) on China state-owned commercial banks.

\subsubsection{F-Test}

In the research, F-tests use the F-statistic to test variable hypotheses5. Through comparing the $\mathrm{P}$ value (Sig.) to examine the independent variables and dependent variables have significant relationships or not. The significance level is 0.05.Ifthe $\mathrm{P}$ value of sample is more than 0.05, it means the independent variable is not significance. If the $\mathrm{P}$ value of sample is less than 0.05, it means the independent variable issignificance(Frost, 2017).

Table 4.9 Model Summaryb

Model $R$ R Square R Square R Square R Square

$\begin{array}{llllll}1 & .654^{\mathrm{a}} & .428 & .419 & 1.42358 & 2.128\end{array}$

Source: Constructed in SPSS 20.0 (2018) 
Based on the table 4.12 Model Summaryb, the result of $\mathrm{R}$ is 0.654 , the result of $\mathrm{R}$ square is 0.428.Therefore, there are $65.4 \%$ correlation of dependent variable and independent variables in this research. Since the coefficient of determination $\mathrm{R}^{2}$ is 0.419 , it indicated that $41.9 \%$ of dependents variable change (Chinese people's decision on China state-owned commercial banks)are affected by three independents variables ( government support, online bank services, bank perceived security),the rest $58.1 \%$ are affected by other factors except government support, online bank services, and bank perceived security in this research.

\subsection{Interpretation of Result and Discussions}

In the chapter 4 of this research, the researchers collected questionnaire data and analysis result by SPSS 20.0. After done the pre-test from 30 respondents, all questionnaire statements are reliable and valid. Through analyzing description analysis and classical assumption, it shows the sample data is normal distribution, it have no multicollinearity problem, no heteroscedasticity problem and no autocorrelation problem.

Ho1: Bank service provision has no impact on Chinese people's decision of China state-owned commercial banks.

Ha1:Bank service provision has a significant impact on Chinese people's decision of China state-owned commercial banks.

Based on the table 4.9, the SPSS output Coefficients shows the value of service provision is 0.304. Since the $0.304>0.05$, the Ho1 is accepted and Ha1 is rejected, it means service provision has not significant impact on Chinese people's decision of State-owned commercial banks.

Chen, Cao, \& Liu(2012) have similar results that service provided by bank include saving, investment accounts, checking accounts,corporate credit card accounts, business loans, property loans and more, the attractiveness of the service provision is service types, service efficiency, service quality. Local small and medium banks pay more attention to its service provision to enhance the market position.

Based on the data analysis and previous research above, in different condition, it produce different results which is no significant effect of online bank services on Chinese people's decision of China state-owned commercial banks.

Ho2: The government support notaffect Chinese people's decision peopleof China state-owned commercial banks.

Ha2:The government supportaffect Chinese people's decisionof China stateowned commercial banks.

Based on the table 4.9 and 4.10 , the SPSS output Coefficients shows the value of government support is 0.04, since the $0.004<0.005$, the Ha2 is accepted and the $\mathrm{Ho} 2$ is rejected. Therefore, government support has a significant impact on Chinese people's decision of State-owned commercial banks.

Brandao-Marques,

Correa \&Sapriza(2013) alsohave similarresultsthat government support effect consumers' decision. Government support for banks decrease the bank's ability of risk taking, a certain extent, government provide bank debt holder guarantees, it improve banks' charter. The government support intensity is related to bank size, liquidity and bank regulations level, it plays an important role in bank development process.

Based on the data analysis and previous research above, there is a significant effect of online bank services on Chinese people's decision of China state-owned commercial banks.

Ho3:Online bank services not 
influence Chinese people's decisionof China state-owned commercial banks.

Ha3:Online bank services influence Chinese people's decisionof China stateowned commercial banks.

Based on the table 4.9 and 4.10 , the SPSS output Coefficients shows the value of online bank services is 0.02. Since the $0.002<0.005$, the Ha3 is accepted and the $\mathrm{Ho} 3$ is rejected. Therefore, online bank services have a significant impact on Chinese people's decision of Stateowned commercial banks.

In addition, Wee, Shie, Cong, Ying\&Hou(2015) alsohave similar opinion to support the result. Online bank services are becoming popular in modern life, with information technology develop in banking industry continually, online bank services as a kind of alternative mechanism, online bank technology reduced unnecessary trouble and improved people's satisfaction, it reducing consumer's dependence on the bank branch and becoming the core of delivery mechanism.

Based on the data result and previous research, there is a significant effect of online bank services on Chinese people's decision of China state-owned commercial banks.

Ho4:Bank perceived securityhave no significant influence on Chinese people's decisionof China state-owned commercial banks.

Ha4: Bank perceived securityhave a significant influence on Chinese people's decisionof China state-owned commercial banks.

Based on the table 4.9 and 4.10 , the SPSS output Coefficients shows the value of bank perceived security is 0.00. Since the $0.000<0.005$, the Ha3 is accepted and the Ho3 is rejected. Therefore, bank perceived security has a significant impact on Chinese people's decision of State-owned commercial banks.

Wee, Shie, Cong, Ying\&Hou(2015) have similar conclusion with the result, when consumer choose a bank, they always consider some common thing, such as bank security, bank reputation and the financial performance have stability or not.in order to give a strong bank security feeling to consumer, building up trust relationship with consumer is very important, once a bank's security get secured, the bank would get trust and preference from consumer.

Based on the analysis of the data and the previous research, there is a significant effect of bank perceived security on Chinese people's decision of China state-owned commercial banks.

Ho5: Bank service provision, government support, online bank services and bank perceived security have no significant influence on Chinese people's decisionof China state-owned commercial banks.

Ha5: Bank service provision, government support, online bank services and bank perceived security have a significant influence on Chinese people's decisionof China state-owned commercial banks.

Based on Table 4.8 Model Summaryb result, the $\mathrm{R}$ Square is 0.428 . That result showed there are three independent variables (X) on the impact towards dependent variable (Y). And then, significant standard values were 0.05, compared to less than the results of 0.00 , this means that three $\mathrm{X}\left(\mathrm{X}_{2}, \mathrm{X}_{3}\right.$, and $\left.\mathrm{X}_{4}\right)$ have an impact on $\mathrm{Y}$.

Zhang, Dong \& Zhu (2012) have similar conclusion with the research results,it shows that contextual factors, brand loyalty, bank security and provided services three independent variables on Chinese people's decision of China state-owned commercial banks. Research shows that with the progress of technology, and the number of banks becoming larger, and the external factors on the impact of consumer decision- 
making more important.

For final result of this study, the government support, online bank services and bank perceived security have a significant influence on Chinese people's decisionof China state-owned commercial banks.

\section{CONCLUSION}

\subsection{Conclusion}

In this chapter, it include conclusion, scope and limitations, and recommendation three parts, through the analysis result of chapter 4, the researchers summarize whether the independent variables (service provision, government support, online bank services and bank perceived security) influence the dependent variable ( Chinese people's decision of China stateowned commercial banks).

1. Service Provision (X1) towards Chinese People's Decision ( $\mathrm{Y}$ ) of China Stateowned Commercial Banks Service provision has no significant influence on Chinese people's decision of China state-owned commercial banks.It means China state-owned commercial banks need to improve their service provision to attract consumers.

2. Government Support (X2) towards Chinese People's Decision (Y) of China State-owned Commercial Banks Government support has a significant influence on Chinese people's decision of China state-owned commercial banks.

3. Online Bank Services $\left(\mathrm{X}_{3}\right)$ towards Chinese People's Decision (Y) of China State-owned Commercial Banks Online bank services have a significant influence on Chinese people's decision of China state-owned commercial banks.

4. Bank Perceived Security (X4) towards Chinese People's Decision (Y) of China State-owned Commercial Banks Bank perceived security has a significant influence on Chinese people's decision of China state-owned commercial banks.

5. Bank service provision (X2), online bank services $\left(\mathrm{X}_{3}\right)$ and Bank perceived security (X4) towards Chinese People's Decision (Y) of China State-owned Commercial Banks

In the research independent variables above, government support, online bank services and bank perceived security are significant variables. There are $41.9 \%$ of dependent variable (Chinese people's decision on China state-owned commercial banks) are affected by three independents variables (government support, online bank services, bank perceived security).

\subsection{Recommendation}

According to the SPSS output analysis in chapter 4, the researchers give some recommendation to China stateowned commercial banks and future researchers.

a. For China state-owned commercial banks:

1. In this research, the analysis result shows the service provision have no significance influence to Chinese people's decision of china state-owned commercial banks. Theresearchers recommends China four state-owned commercial banks should focus on its ownareaandprovidemoreprofessional bank services to consumers, like $\mathrm{ABC}$ (Agricultural Bank of China) support village agriculture by bank policy. So that consumers can choose bank products and services based on their needs, and make more consumers get benefits from the China state-owned commercial banks.

2. The SPSS output analysis result shows the government support, online bank services, bank perceived security have a significance influence to Chinese 
people's decision of China state-owned commercial banks. Theresearchers recommends the Big Four(four stateowned commercial banks in China) should improve the influence of government support, ensure more consumers recognize China stateowned commercial banks' security. And then, since online bank service is an innovative bank product and service, the banks should constantly improve the online banking system to make consumers accept the value more easily.

b. For future researchers:

1. According to the SPSS output model summary analysis in chapter 4 , there are $58.1 \%$ are affected by other factors except government support, online bank services and bank perceived security. Therefore, future researchers can research more factors that affecting Chinese people's decision of China state-owned commercial banks, like bank brand, advertising effect and bank innovation.

2. In order to get more exact analysis result in this research, the future researchers should spread more questionnaires to more people, like Chinese people all over the world.

3. In order to get more theory to support this research topic, the future researchers should search more famous literatures all over the world, like useful journals, foreign books and newspaper report.

\section{BIBLIOGRAPHY}

\section{Journals}

Ainiyah, N., Deliar, A., \&Virtriana, R. (2016). The Classical Assumption Test to Driving Factors of Land Cover. Change in the Development Region of Northern Part of West Java. The International Archives of the Photogrammetry, Remote
Sensing and Spatial Information Sciences, Volume XLI-B6

Brandao-Marques, L., Correa, R., \&Sapriza, H. (2013).International Evidence on Government Support and Risk Taking in the Banking Sector. Social Science Research Network electronic library

Chan, K., Tseng, L., \& Chen, J. (2017). Marketing Bank Services to Youth in China Journal of Young Consumers.Vol.18 (3). 278-289

Chen, L., Cao, W., \& Liu, Y. (2016). The relationship between bank service quality,consumer satisfaction and consumer loyalty. Web Journal of Chinese Management Review. Vol.19 (1). 22-36

Esterik-Plasmeijer, P., \&Raaij, W. (2017).Bank System Trust, Bank Trust, Bank Trust, and Bank Loyalty.International Journal of Bank Marketing.Vol.35 (1).97-111.

Jin, D., Liu, J., Liu, L., \& Yin, D. (2014). Competition and Profit Hiding: Evidence from Banks in China. Journal of Managerial Finance. Vol.40 (10).1040-1051.

Laforet, S., \& Li, X. (2015). Consumers' Attitudes Towards Online and Mobile Banking in China. International Journal of Bank Marketing. Vol. 23(5).362-380

Lee, K. D., In, J., \& Lee, S. (2015). Standard Deviation and Standard Error of The Mean. Korean Journal Anesthesiology.Vol. 28(3). 220-223

Levy, S. (2014). Does Usage Level of Online Services Matter To Consumers' Bank Loyalty? Journal of Services Marketing. Vol. 28(4) 292-299.

Mekovec, R., \& Hutinski, Ž. (2012). The role of perceived privacy and perceived security online market. Journal of Business \& Management. Vol.5 (1).179-198.

Nyman, H. (2014). The Added Value 
of Service Provision.International Journal of Bank Marketing.Vol. 32(6).457-476.

Tinnilä, M. (2013). Efficient service production: service factories in banking. Business Process Management Journal, Vol. 19(4). 648-661

Tan, Y., \&Floros, C. (2012). Bank Profitability and Inflation: The Case of China. Journal of Economic Studies.Vol. 39(6).675-696.

Tan, Y., \&Floros, C. (2012). Stock Market Volatility and Bank Performance In China. Studies in Economics and Finance.Vol. 29(3). 211-118

Wang, M., Cho, S., \& Denton, T. (2017). The impact of personalization and compatibility with past.Experience on E-banking Usage.International Journal of Bank Marketing,.Vol.35 (1). $45-55$.

Wee, G., Shie, L., Cong, N., Ying, W., \&Hou, Y. (2015).Factors That Influence The Consumer Behavior On Choices Of Local Commercial Bank For Banking Products And Services In Perak. Management Journal of Contemporary Management. Vol.16. 87-103.

Yang, L. (2012).Consumer Satisfaction Antecedents Within Service Recovery Context: Evidences from "Big 4" banks in China", Nankai Business Review International. Vol3.(3).284-301.

Yin, W., \& Matthews, K. (2017).Bank Lending and Bank Relationships in China: Guang Xi or Commercial? Managerial Finance.Vol.43(4).425439.

Zineldin, M. (2017).Bank Strategic Positioning and Some Determinants of Bank Selection.International Journal of Bank.Vol.14 (6).12-22

Zhang, Q., Dong, Z., \& Zhu, Z. (2012). Study on Consumer Channel Preferences of Commercial Banks.
Journal of Xi'an Technological University.Vol.32 (1).04-043

Book:

Creswell, J. (2014). Research Design. (Qualitative, Quantitative, and Mixed Methods Approaches).4th Edition.SAGE Publications, Inc.

Liew, L. (2012). A State Enterprise in China's Capitalist Transformation: The Political Economy of Stateowned Enterprises in China and India.Palgrave Macmillan, a division of Macmillan Publishers Limited 2012.

Edmonds, T. (2017).Government Bank Rescues: Financial Consequences. Maintaining Financial Stability of Banks.Public Accounts Committee in Publication.

Website:

Annum,G.(2017). Research Instruments For Data Collection http:// c a m pus.educadium . com / newmediart/file.php/137/Thesis_ Repository/recds/assets/TWs/ UgradResearch/ThesisWrit4all/ files/notes/resInstr.pdf

Bremer, M. (2012) Multiple Linear Regression http://mezeylab. cb.bscb.cornell.edu/labmembers/ documents/supplement\%205\%20 -\%2omultiple\%2oregression.pdf

DeFranzo, S. (2012). What's The Difference Between Qualitative and Quantitative Research?https:// www.snapsurveys.com/blog/ qualitative-vs-quantitativeresearch/

Flekel, A. (2013). 5 Steps of Decision Making Process.https://www. business 2 community.com/ marketing/5-steps-of-decisionmaking-process-0480178

Frost, J. (2016). How F-tests work in Analysis of Variance (ANOVA) http://statisticsbyjim.com/anova/ f-tests-anova/

Heffner, C. (2014). Chapter 7.3 Test 
Validity and Reliability.https:// allpsych.com/researchmethods/ validityreliability/

Vanek, C. (2012). What is it? When to Use it? How to Analyze it? https:// www.surveygizmo.com/surveyblog/likert-scale-what-is-it-howto-analyze-it-and-when-to-use-it/.

Xin, J., Yang, X., Yang, Z., Wang, X., \& Tao, Y. (2016). China's Banking Development Trend Report 2017-Commercial Bank. http:// epaper.21jingji.com/html/201612/01/content_51587.htm

Zamboni, J. (2017). What Is the Meaning of Sample Size? What Is the Meaning of Sample Size? https:// sciencing.com/meaning-samplesize-5988804.html 